\title{
Artykuły
}

JULIAN KRZYŻANOWSKI

DOI: $10.5604 / 00441600.1184577$

Instytut Ekonomiki Rolnictwa

i Gospodarki Żywnościowej - PIB

Warszawa

\section{WYRÓWNYWANIE POZIOMU PŁATNOŚCI BEZPOŚREDNICH W POLSCE DO POZIOMU INNYCH KRAJÓW UNII EUROPEJSKIEJ}

\begin{abstract}
Abstrakt
Artykut porusza problematyke wyrównywania poziomu płatności bezpośrednich w krajach Unii Europejskiej. Zaprezentowano dwa zestawy wskaźników i ich ewolucję: stawke płatności do danego produktu i na hektar uprawnionej powierzchni. W artykule zwraca sie uwage na potrzebe redystrybucji płatności, a nastepnie przedstawia różne jej scenariusze. Na koniec prezentuje się model płatności przyjęty przez kraje i instytucje UE, a także zmiany $w$ wysokości płatności bezpośrednich na 1 ha wynikajace $z$ redystrybucji. Wyniki rachunku wskazuja na wzrost poziomu płatności bezpośrednich w Polsce, ale jest on nadal nieznacznie poniżej średniej w krajach $U E$.
\end{abstract}

Słowa kluczowe: płatności bezpośrednie, Unia Europejska, reforma Mc Sharry’ego, stawki płatności, plon referencyjny, redystrybucja płatności

\section{Wprowadzenie}

Wyrównywanie płatności bezpośrednich, podstawowej formy wsparcia dla rolników w krajach UE, jest nośnym hasłem, wielokrotnie głoszonym przez polityków, którzy często nie wiedzą lub są niewłaściwie informowani, na czym polega istota sprawy.

Jest tu bowiem co najmniej kilka problemów. 
Wyrównywać do czego - do średniej w Unii Europejskiej, czy może do poziomu krajów, które otrzymują najwięcej? Druga kwestia, co wyrównywać? - zapewne finalnie stawkę na hektar użytków rolnych. Ale mówiąc o niższych płatnościach w stosunku do innych krajów UE w momencie akcesji, mamy też kwestię niepełnej płatności do określonego produktu. Czyli w punkcie wyjścia możemy mówić o podwójnym braku wyrównania:

- do stawek płatności (produkt/ ilość), które wprawdzie już nie obowiązują, ale z ich wysokości wynika wielkość płatności także obecnie;

- do płatności na hektar UR.

By spróbować rozwiązać ten problem, musimy cofnąć się do lat dziewięćdziesiątych ubiegłego stulecia. W 1992 r. (za czasów komisarza MacSharry’ego) wprowadzono system płatności bezpośrednich. Miał on pierwotnie rekompensować obniżkę cen interwencyjnych, w praktyce stał się jednak dodatkowym środkiem powiększania dochodów rolniczych lub rekompensaty ich spadku (Krzyżanowski, 2015). Kwestię wysokości stawek płatności i całego dalszego rachunku najprościej można przedstawić na przykładzie płatności do zbóż. W rozłożonej na 3 lata reformie cena docelowa zbóż, z wyjątkiem ryżu, miała wynosić w trzecim roku 100 ECU za 1t (ECU - wspólna jednostka obrachunkowa, przelicznik w 1992 r. - 1 ECU = 1,29 USD). Proponowana wysokość ceny docelowej powinna odpowiadać poziomowi cen zbóż na rynku światowym, przy założeniu jego stabilizacji. W 1992 r. przeciętna cena rynkowa zbóż w krajach WE wynosiła 155 ECU. Rolnikom miała być rekompensowana strata przychodów w wysokości 55 ECU za 1t. Stanowiła ona różnicę między aktualną ceną rynkową zbóż 155 ECU za lt a poziomem ceny docelowej 100 ECU za $1 \mathrm{t}$. Wysokość tej płatności mogła zmieniać się wraz ze zmianami plonów, a także ogólną sytuacją na rynku unijnym i zagranicznym. Stawki subsydiów przeliczane na jednostkę powierzchni były ustalane regionalnie w zależności od wysokości średnich plonów osiąganych w ciągu kilku lat poprzedzających reformę. Dla przykładu, średnie plony dla całej Wspólnoty liczone w powyższy sposób wynosiły 4,6 t z 1 ha, a zatem wielkość płatności wynosiła 253 ECU/ha $(4,6 \mathrm{t} / \mathrm{ha} \bullet 55 \mathrm{ECU} / \mathrm{t})$. W pierwszym roku reformy płatność wynosiła $30 \mathrm{ECU} / \mathrm{t}$, czyli 138 ECU na 1 ha; w drugim roku 45 ECU/t, czyli 207 ECU na 1 ha, i dopiero $\mathrm{w}$ trzecim roku zakładano osiągnięcie wielkości docelowych. Zmiana wysokości płatności wynikała z kolejnych obniżek ceny docelowej w pierwszym roku do $125 \mathrm{ECU} / \mathrm{t}$, a w drugim - do $110 \mathrm{ECU} / \mathrm{t}$ (Krzyżanowski, 1993).

W systemie obecnie nazywanym historycznym, klasycznym bądź standardowym formuła liczenia płatności jest więc następująca:

powierzchnia bazowa $\bullet$ stawka płatności/t $\bullet$ plon $\bullet$ kurs zł/euro

$$
=\text { tzw. koperta na zboża }
$$

Stawka płatności na 1 ha wyniknie z podzielenia koperty przez ilość hektarów, które zgłaszają rolnicy ubiegający się o płatności.

Mamy więc do rozpatrzenia kształtowanie się dwu wielkości: „unijnej” stawki płatności oraz wielkości plonu przyjmowanego do rachunku. 


\section{Stawki płatności}

Wysokość stawek płatności stopniowo podwyższano w kolejnych latach, a następnie zmieniono pakietem reform z 1997 r. (tzw. Agenda 2000.). Płatności bezpośrednie dla najważniejszych produktów na początku obecnego stulecia przedstawia tabela 1 .

Tabela 1

Płatności bezpośrednie stosowane w UE do $2005 \mathrm{r}$.

\begin{tabular}{|c|c|c|c|}
\hline Produkt & 2000/01 & 2001/02 & $2002 / 03$ \\
\hline Zboża (EUR/t) & 58,67 & 63,00 & 63,00 \\
\hline Rośliny oleiste (EUR/t) & 81,74 & 72,37 & 63,00 \\
\hline Rośliny wysokobiałkowe (EUR/t) & 72,50 & 72,50 & 72,50 \\
\hline Len i konopie włókniste (EUR/t) & 88,26 & 75,63 & 63,00 \\
\hline Kiszonka z trawy $(\mathrm{EUR} / \mathrm{t})$ & 58,67 & 63,00 & 63,00 \\
\hline \multicolumn{4}{|l|}{ Specjalna premia wołowa (EUR/szt.): } \\
\hline - buhaje & 160 & 185 & 210 \\
\hline - wolce & 122 & 136 & 200 \\
\hline Krowy mamki (EUR/szt.) & 163 & 182 & 200 \\
\hline \multicolumn{4}{|l|}{ Premia za ubój (EUR/szt.): } \\
\hline - byki, wolce, krowy i jałówki & 27 & 53 & 80 \\
\hline - cielęta & 17 & 33 & 50 \\
\hline $\begin{array}{l}\text { Premia za ekstensyfikację produkcji } \\
\text { (EUR/szt.) }\end{array}$ & 100 & 100 & 100 \\
\hline Owce (EUR/szt.) & 21 & 21 & 21 \\
\hline Skrobia ziemniaczana (EUR/t) & 98,74 & 110,54 & 110,54 \\
\hline Susze paszowe (EUR/t) & 68,83 & 68,83 & 68,83 \\
\hline Chmiel (EUR/ha) & 480 & 480 & 480 \\
\hline \multicolumn{4}{|l|}{ Tytoń (EUR/t) } \\
\hline - Virginia & 2980,62 & 2980,62 & 2980,62 \\
\hline - Burley & 2384,23 & 2384,23 & 2384,23 \\
\hline - Dark air cured & 2384,23 & 2384,23 & 2384,23 \\
\hline - Fired cured & 2621,99 & 2621,99 & 2621,99 \\
\hline
\end{tabular}

$\overline{\text { Źródło: Krzyżanowski, } 2015 .}$

Pierwszym punktem odniesienia do dalszych rozważań jest zatem stawka dopłaty do tony zbóż, w momencie kończenia negocjacji akcesyjnych, w wysokości 63 euro. 


\section{Stawka płatności dla nowych krajów członkowskich}

Komisja Europejska przez cały okres trwania negocjacji akcesyjnych sprzeciwiała się wypłacaniu pełnych unijnych stawek pomocy bezpośredniej rolnikom z nowych państw członkowskich. Argumentowano, iż w świetle dużej rozbieżności pomiędzy poziomem PKB na Wschodzie i na Zachodzie, gwałtowny napływ wysokich płatności pomocowych zakłóciłby gospodarkę obszarów wiejskich w Europie Srodkowej i Wschodniej oraz spowodował wzrost inflacji. Zdaniem Komisji, wypłata pełnych stawek płatności bezpośrednich w 10 nowych państwach członkowskich byłaby także dużym obciążeniem dla budżetu UE (Krzyżanowski, 2009).

Ostatecznie osiągnięte zostało porozumienie kompromisowe, przewidujące 10-letni okres przejściowy, w czasie którego stawki w nowych państwach członkowskich miały być stopniowo zwiększane, aż do osiągnięcia pełnego poziomu obowiązującego w starych państwach członkowskich (począwszy od $25 \%$ pełnej stawki w roku pierwszym, tj. 2004). Uzgodniono jednak także, że nowe państwa członkowskie będą mieć możliwość przyznawania swoim rolnikom płatności uzupełniających w wysokości $30 \%$ pełnej stawki UE. Oznaczało to, że w rzeczywistości rolnicy mogli otrzymywać do 55\% pełnej stawki pomocy UE w pierwszym roku. Krajowe płatności uzupełniające zmalały do $20 \%$ w $2011 \mathrm{r}$. i do $10 \%$ w 2012 r., kiedy to wkład UE osiągnął odpowiednio 80\% i 90\%.

Harmonogram płatności pomocy w nowych państwach członkowskich zamieszczono poniżej.

Tabela 2

Stawki płatności bezpośrednich w nowych krajach członkowskich (w\% petnej stawki UE):

\begin{tabular}{lccc}
\hline Rok & Stawka UE & Krajowe płatności uzupełniające & Maksymalna płatność łącznie \\
\hline 2004 & 25 & 30 & 55 \\
2005 & 30 & 30 & 60 \\
2006 & 35 & 30 & 65 \\
2007 & 40 & 30 & 70 \\
2008 & 50 & 30 & 80 \\
2009 & 60 & 30 & 90 \\
2010 & 70 & 30 & 100 \\
2011 & 80 & 20 & 100 \\
2012 & 90 & 10 & 100 \\
2013 & 100 & 0 & 100
\end{tabular}

Źródło: Krzyżanowski, 2009.

Pełne stawki unijne (63 euro/t w przypadku zbóż) Polska otrzymywała zatem od roku 2013. Można więc uznać, że pierwsze wyrównanie płatności (stawek) nastąpiło. 


\section{Plon referencyjny}

Drugą wielkością uwzględnianą w rachunku płatności bezpośrednich była wielkość plonu. Skoro ustalono stawkę za tonę produkcji, należało zbadać, jaka jest jej wysokość z jednostki powierzchni produkcyjnej. W pierwszych latach funkcjonowania reformy Mc Sharry'ego do kalkulacji przyjmowano średnie plony zbóż w Unii Europejskiej. Po kilku latach stwierdzono jednak, że należy premiować wyższą wydajność produkcji i - zgodnie z Rozporządzeniem Rady 1251/99 i 2316/99 - Unia Europejska zaczęła uwzględniać plony krajowe z lat 1986/87 - 1990/91, czyli tzw. okresu referencyjnego, stąd nazwa plonu (Kowalski, Rowiński i Wigier, 2001).

Wielkość plonów referencyjnych w krajach UE była wysoce zróżnicowana: np. w Hiszpanii 2,69 t/ha, a w Holandii 6,66 t/ha. Polska w swoim stanowisku negocjacyjnym występowała o ustalenie plonu dla zbóż w wysokości 3,61 t/ha (Stankiewicz, 2001). Ostatecznie, po długich negocjacjach (była to druga kwestia, obok wysokości kwot mlecznych, zamykająca sprawy rolne), wysokość plonu referencyjnego dla Polski ustalono na poziomie 3,0 t/ha. Skoro o wielkości płatności decydowała w gruncie rzeczy wysokość plonów, nic dziwnego, że płatności dla Polski były dużo mniejsze od kwot wypłacanych w krajach Europy Zachodniej.

\section{Redystrybucja płatności bezpośrednich}

W dalszej części opracowania pominięto kolejne reformy systemu płatności bezpośrednich, nie jest to bowiem głównym celem niniejszych badań. Istotne są natomiast kształtowanie się wielkości podstawowych płatności bezpośrednich na 1 hektar uprawnionej powierzchni w krajach członkowskich UE oraz możliwości zmniejszenia różnic w ich wysokości (wyrównania).

Przez przyjęcie do rachunku wielkości plonów referencyjnych, o znacznym zróżnicowaniu miedzy poszczególnymi krajami, wielkość płatności była także różna, co wyraźnie ilustruje rysunek $1 \mathrm{i}$ tabela 3 . W tabeli pokazano też hipotetyczne wyrównanie płatności do średniej unijnej, tj. 285 euro/ha.

Różnice w wielkości płatności na 1 ha były szczególnie znaczące między „starymi” a „,nowymi” krajami UE, przyjętymi do ugrupowania w r. 2004 i w latach następnych. „Nowe” kraje członkowskie po kilku latach funkcjonowania w systemie dopłat bezpośrednich zdały sobie sprawę, że nie można opierać systemu płatności o parametry historyczne. Tym bardziej że płatności bezpośrednie miały wspierać dostarczanie przez rolnictwo tzw. dóbr publicznych, także przez gospodarstwa mniej wydajne. Polska należała do czołówki krajów, które domagały się wyrównania płatności.

Ostatnia poważna reforma, która nadała kształt Wspólnej Polityce Rolnej do 2013 r., została uchwalona w 2003 r. w Luksemburgu (Krzyżanowski, 2015). Wśród postanowień dotyczących modyfikacji istniejących instrumentów WPR znalazło się również postanowienie o przeprowadzeniu oceny funkcjonowania WPR (ang. Health Check) w 2008 r. 
Przegląd wytyczał także kierunki przyszłych zmian WPR (po roku 2013). Zdefiniowano bowiem i dołączono do listy celów WPR ,nowe wyzwania”, dotyczące zmian klimatycznych, energii odnawialnej, gospodarki wodnej, różnorodności biologicznej, środków towarzyszących, restrukturyzacji mleczarstwa oraz innowacyjności w zakresie czterech pierwszych zadań. Dla trwającej dyskusji o przyszłości WPR szczególnie istotne było także zobowiązanie Komisji Europejskiej i Rady do przeanalizowania problemu dużego zróżnicowania płatności bezpośrednich w skali UE i przedstawienia propozycji odpowiednich zmian.

W ramach „Health Check” opracowano projekt tzw. płatności ryczałtowej (flat rate).

W następnych latach (2008-2013) rozpatrywano inne warianty. Dyskusja toczyła się na różnych forach (http://ec., 2013). Stwierdzono (Commission, 2011), że dystrybucja płatności bezpośrednich powinna w większym stopniu odzwierciedlać podwójną rolę tych płatności, polegającą na wsparciu dochodów i dostarczaniu dóbr publicznych, poprzez lepsze dostosowanie celów polityki do dostępnych środków budżetowych (Cooper, Hart i Baldock, 2009). Jednocześnie, aby uniknąć poważnych zakłóceń, konieczne było uwzględnienie obecnego podziału płatności bezpośrednich. Przewidywano kilka opcji redystrybucji kopert płatności bezpośrednich pomiędzy państwa członkowskie:

- „stawka ryczałtowa dla całej UE”: płatności bezpośrednie są wypłacane w zależności od łącznej liczby potencjalnie kwalifikowalnych hektarów w państwach członkowskich;

- podejście pragmatyczne: dostosowanie (w ograniczonym zakresie) istniejących zasad podziału środków, w celu uniknięcia poważnych zakłóceń, do obecnych poziomów płatności bezpośrednich, przy jednoczesnym ustanowieniu ogólnounijnego poziomu płatności na hektar na podstawie udziału w średniej UE;

- zastosowanie kryteriów obiektywnych: stawka ryczałtowa dla całej UE uwzględnia obiektywne kryteria oparte na wskaźnikach ekonomicznych, fizycznych lub środowiskowych;

- połączenie podejścia pragmatycznego i kryteriów obiektywnych.

Należy zaznaczyć, że w symulacjach tych nie uwzględniono kwestii okresu i warunków ewentualnego przejścia do nowych zasad podziału, które również zależeć będą od ostatecznego poziomu redystrybucji. Ustalenie okresu przejściowego miało istotne znaczenie nie tylko dla państw członkowskich, których krajowe koperty płatności bezpośrednich uległyby zmniejszeniu, ale również dla tych państw członkowskich, które skorzystałyby na wzroście. W niektórych przypadkach przychody z płatności bezpośrednich na hektar wynikające z poniższych opcji mogłyby nie tylko wpłynąć na wzrost cen gruntów, ale także stanowić przeszkodę dla zmian strukturalnych, ponieważ mogły zniechęcać rolników do restrukturyzacji, rozwoju i poprawy rentowności gospodarstw.

Punktem wyjścia dla symulacji jest bieżący poziom płatności bezpośrednich na hektar, obliczany w taki sposób, że kwota koperty płatności bezpośrednich dla każdego państwa członkowskiego (przy zakończeniu mechanizmu phasing- 
-in w UE-12 i uwzględnieniu modulacji na poziomie 2013 r.) dzielona jest przez wielkość potencjalnego obszaru kwalifikującego się do systemu jednolitej płatności obszarowej, zadeklarowanego przez rolników, o którym państwo członkowskie poinformowało Komisję w ramach systemu IACS.

Tabela 3

Płatności bezpośrednie na 1 ha UR w krajach UE: propozycje wyrównania średniej unijnej oraz płatności liczone wg nowej formuty

\begin{tabular}{|c|c|c|c|c|c|}
\hline & Kraj & $\begin{array}{l}\text { Płatności } \\
\text { na hektar } \\
2013 \\
\text { euro/ha }\end{array}$ & $\begin{array}{l}\text { Redystrybucja wyrównania } \\
\text { płatności na hektar } \\
\text { dla UE-27 przy średniej } \\
285 \text { euro/ha }\end{array}$ & $\begin{array}{c}\text { Zmiany } \\
2013 \\
(\mathrm{w} \%)\end{array}$ & $\begin{array}{c}\text { Docelowa } \\
\text { płatność na } 1 \text { ha } \\
\text { ustalona po } \\
\text { "Health Check" }\end{array}$ \\
\hline 1 & Rumunia & 183 & 102 & 56 & 208 \\
\hline 2 & Bułgaria & 233 & 52 & 22 & 241 \\
\hline 3 & Estonia & 117 & 168 & 144 & 164 \\
\hline 4 & Litwa & 144 & 141 & 98 & 182 \\
\hline 5 & Polska & 215 & 70 & 33 & 229 \\
\hline 6 & Słowacja & 206 & 79 & 38 & 223 \\
\hline 7 & Węgry & 260 & 25 & 10 & 259 \\
\hline 8 & Czechy & 257 & 28 & 11 & 257 \\
\hline 9 & Słowenia & 325 & -40 & -12 & 302 \\
\hline 10 & Cypr & 372 & -87 & -23 & 334 \\
\hline 11 & Malta & 696 & -411 & -59 & 550 \\
\hline 12 & Łotwa & 95 & 190 & 200 & 149 \\
\hline 13 & Portugalia & 194 & 91 & 47 & 215 \\
\hline 14 & W. Brytania & 229 & 56 & 24 & 238 \\
\hline 15 & Hiszpania & 229 & 56 & 24 & 238 \\
\hline 16 & Austria & 262 & -4 & -1 & 260 \\
\hline 17 & Szwecja & 235 & 50 & 21 & 242 \\
\hline 18 & Finlandia & 237 & 48 & 20 & 244 \\
\hline 19 & Luksemburg & 275 & 10 & 4 & 269 \\
\hline 20 & Francja & 296 & -11 & -4 & 283 \\
\hline 21 & Irlandia & 271 & 14 & 5 & 266 \\
\hline 22 & Niemcy & 319 & -34 & -11 & 298 \\
\hline 23 & Włochy & 404 & -119 & -29 & 355 \\
\hline 24 & Dania & 363 & -78 & -21 & 328 \\
\hline 25 & Belgia & 435 & -150 & -34 & 376 \\
\hline 26 & Holandia & 457 & -162 & -35 & 390 \\
\hline 27 & Grecja & 384 & -99 & -25 & 342 \\
\hline
\end{tabular}

Źródło: Capreform, 2015 i obliczenia własne. 


\section{Stawka ryczałtowa dla całej UE}

Jedną z opcji, wynikłą na gruncie debaty publicznej, było odejście od odniesień historycznych w stronę ogólnounijnej „stawki ryczałtowej” (lub „średniej UE"), o tym samym poziomie środków na hektar dla wszystkich rolników w UE (por. tabela 3).

Jak wynika z tabeli 3, istniejące poziomy płatności bezpośrednich na Malcie, w Belgii, Holandii, Włoszech, Grecji, na Cyprze, w Danii oraz Słowenii są znacznie wyższe od średniej, natomiast płatności w krajach bałtyckich, Portugalii, Rumunii, Słowacji, Bułgarii oraz Polsce (czyli głównie w nowych państwach członkowskich) znacznie niższe.

Opcja ta skutkowałaby zatem stratami dla Malty, Belgii, Holandii, Włoch, Grecji, i Danii oraz istotnymi zyskami dla krajów bałtyckich, Portugalii i Rumunii.

Jak wyjaśniono jednak w Komunikacie Komisji (Komunikat 2010), stawka ryczałtowa płatności dla całej UE nie odzwierciedlałaby różnic w sytuacji gospodarczej i środowiskowej państw członkowskich, ponieważ dany poziom płatności w różnoraki sposób wpływa na dochód, a każdy hektar w inny sposób przyczynia się do dostarczania środowiskowych dóbr publicznych. Trzeba pamiętać również o tym, że ziemie uprawne są bardzo nierówno rozdzielone pomiędzy gospodarstwa: w UE-25 prawie $90 \%$ gruntów znajduje się w posiadaniu $20 \%$ gospodarstw (Annex, 2015). Dlatego też przejście na stawkę ryczałtową dla całej UE o takiej samej kwocie płatności bezpośrednich na hektar nie rozwiązałoby problemu nierównego podziału płatności bezpośrednich pomiędzy gospodarstwa rolne, ze względu na struktury rolnictwa w UE.

\section{Podejście pragmatyczne}

Kolejną opcją, o której mowa w Komunikacie Komisji, było przyjęcie podejścia pragmatycznego, np. poprzez uzgodnienie, że państwa członkowskie otrzymują co najmniej $80 \%$ średniej UE na hektar.

Według stanu podziału środków z 2013 r., 8 państw członkowskich nie przekraczało progu $80 \%$, a dziewiętnaście państw członkowskich osiągało wartość przewyższającą średnią UE. Koszt podniesienia poziomu płatności na hektar do 80\% średniej UE (tj. wg naszych wyliczeń - 228 euro/ha) w państwach, które nie osiągają tego progu, zostałby pokryty przez 19 państw członkowskich przekraczających poziom średniej UE. Wymagałoby to redukcji ich kopert krajowych.

Opcja ta umożliwiłaby działania na rzecz poprawy sytuacji państw członkowskich znajdujących się znacznie poniżej średniej UE, przy jednoczesnym zmniejszeniu wpływu redystrybucji z państw przekraczających średni poziom.

Rozważano również wprowadzenie zapisu, że państwa członkowskie, w których poziom płatności bezpośrednich kształtuje się poniżej 90\% średniej UE, zamkną 1/3 luki między ich obecnym poziomem a poziomem $90 \%$, co przedstawiono na rysunku 1. 


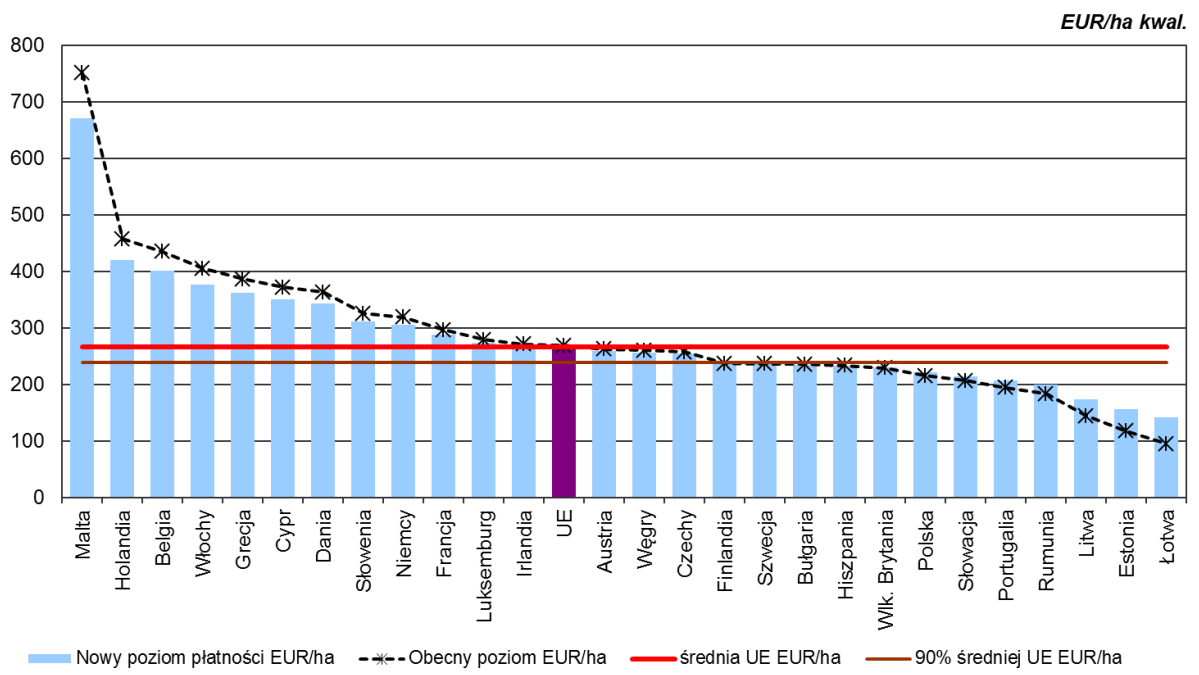

Rys.1. Redystrybucja płatności - jedna trzecia różnicy pomiędzy obecnym poziomem a 90\% średniej UE.

Źródło: (propozycje, 2015).

Opcja ta wiązałaby się z mniejszą konwergencją dla państw członkowskich nieprzekraczających poziomu $90 \%$ średniej UE.

Zastanawiano się również nad wprowadzeniem zapisu, że wszystkie państwa członkowskie otrzymują co najmniej $80 \%$ i żadnemu z nich nie przysługuje więcej niż $120 \%$ stawki ryczałtowej (opcja zwana także w dokumentach UE - „Tunel $80 \%$ - 120\%”). Ta opcja byłaby zbliżona do stawki ryczałtowej. Koszt konwergencji poniosłaby wówczas mniejsza niż w innych wariantach liczba państw członkowskich.

\section{Zastosowanie kryteriów obiektywnych}

Kolejna opcja zakładała oparcie zasad podziału środków na kryteriach obiektywnych (odzwierciedlających podwójną rolę płatności bezpośrednich, polegającą na wsparciu dochodów oraz dostarczaniu dóbr publicznych), które zapewniłyby bardziej sprawiedliwe i wydajniejsze wykorzystanie zasobów budżetowych.

Potencjalne kryteria obiektywne mają bardzo zróżnicowany charakter, w związku z czym bardzo różni się poziom redystrybucji płatności bezpośrednich, z uwagi na specyficzną sytuację gospodarczą i środowiskową każdego kraju.

Przedmiotem najbardziej ożywionej debaty instytucjonalnej i publicznej były następujące kryteria:

- spośród ogólnych kryteriów ekonomicznych - poziom siły nabywczej i PKB per capita: wskaźnik ten jest wykorzystywany przy korektach w odniesie- 
niu do średniej UE w przypadku państw członkowskich o wyższym PKB per capita (korygowanym poziomem siły nabywczej), otrzymujących wyższe płatności bezpośrednie na 1 ha. Kryteria te odzwierciedlałyby rozbieżności w kosztach życia między państwami członkowskimi;

- spośród kryteriów ekonomicznych związanych z rolnictwem - roczna jednostka pracy (z ang. annual working unit - AWU) i WDB/AWU (wartość dodana brutto na AWU): porównywano średni wskaźnik dla UE ze wskaźnikiem dla państw członkowskich o najwyższej WDB/AWU, otrzymujących wyższe płatności bezpośrednie na 1 ha. Kryteria te odzwierciedlałyby różnice w produktywności sektorów rolnictwa państw członkowskich;

- spośród kryteriów środowiskowych brano pod uwagę tereny na obszarach o niekorzystnych warunkach gospodarowania (ONW), strefy Natura 2000 i trwałe użytki zielone. Wskaźnik ten porównuje udział tych obszarów w łącznej powierzchni użytków rolnych państwa członkowskiego do średniej UE. W tym przypadku państwa członkowskie, w których udział ten jest wyższy, otrzymują wyższe płatności bezpośrednie na 1 ha. Kryteria te odzwierciedlają niekorzystne warunki określonych obszarów lub obszary, które są szczególnie ważne pod względem dostarczania dóbr publicznych.

Można też połączyć obiektywne kryteria ekonomiczne i środowiskowe w celu dostosowania stawki ryczałtowej dla całej UE, na podstawie poniższego wzoru (przyjmując wagę 2/3 dla kryteriów ekonomicznych i 1/3 dla kryteriów środowiskowych):

Stawka ryczałtowa $\bullet[2 / 3 \cdot[(2 / 3 \mathrm{PKB}$ per capita $+1 / 3 \mathrm{WDB} / \mathrm{AWU})]+1 / 3(1 / 3$

ONW $+1 / 3$ trwałych użytków zielonych $+1 / 3$ obszarów Natura 2000)] .

Zastosowanie obiektywnych kryteriów, przy nadaniu większej wagi kryteriom ekonomicznym, uwidoczniłoby lukę między UE-15 a UE-12. Krajami, których sytuacja w wartościach bezwzględnych najbardziej by się poprawiła, byłyby państwa członkowskie UE-15: Wielka Brytania, Hiszpania i Francja. Przy kryteriach środowiskowych najwięcej zyskałyby: Hiszpania, Wielka Brytania i Portugalia. W przypadku połączenia kryteriów ekonomicznych i środowiskowych największe korzyści odniosłyby: Hiszpania, Wielka Brytania i Irlandia, a największymi przegranymi byłyby Włochy, Grecja i Polska (Commission, 2011).

Podstawowy problem przy wyborze tej opcji polegał na tym, że spowodowałaby ona redystrybucję na ogromną skalę, co dla wielu państw członkowskich byłoby politycznie nie do zaakceptowania.

\section{Połączenie podejścia pragmatycznego i kryteriów obiektywnych}

Można budować różne sposoby łączenia kryteriów obiektywnych, przy jednoczesnym uwzględnieniu celu konwergencji i obecnego podziału środków, jak np.:

- zapewnienie minimalnego poziomu konwergencji (np. wszystkie państwa członkowskie otrzymują co najmniej 90\% średniej UE), przy zastosowaniu 
obiektywnego kryterium służącego określeniu poziomu państw członkowskich przekraczających obecnie średnią UE;

- zastosowanie kryteriów obiektywnych w odniesieniu do różnicy między bieżącym stanem podziału środków a średnią UE, aby zagwarantować, że państwa członkowskie przekraczające stawkę ryczałtową będą ograniczać swoje płatności bezpośrednie, ale nie zmniejszą ich poniżej poziomu stawki ryczałtowej, a te, które jej nie przekraczają, będą zwiększać płatności bezpośrednie, pozostaną jednak poniżej jej poziomu.

Podczas posiedzenia Rady Ministrów UE ds. Rolnictwa i Rybołówstwa w dniach 18-20 listopada 2008 r. nastąpiło przyjęcie ostatecznego porozumienia, kończącego dyskusje w ramach przeglądu Health Check (Sprawozdanie, 2008). Wynikiem przeglądu było przyjęcie aktów prawnych, modyfikujących podstawy funkcjonowania Wspólnej Polityki Rolnej.

Ustalono sposób konwergencji płatności bezpośrednich pomiędzy państwami członkowskimi (w ramach rozstrzygnięć dotyczących Wspólnych Ram Finansowych - WRF). W państwach członkowskich z płatnościami bezpośrednimi na hektar poniżej $90 \%$ średniej UE różnica między obecnym poziomem płatności a 90\% średniej UE ma być zmniejszona o jedną trzecią. Proces ten będzie przeprowadzany stopniowo, od roku budżetowego 2015 do roku budżetowego 2020. Docelowo wszystkie państwa członkowskie mają osiągnąć poziom płatności co najmniej w wysokości 196 euro/ha (w cenach bieżących). Powyższa konwergencja zostanie sfinansowana przez kraje, w których płatności bezpośrednie są wyższe od średniej UE.

Widać więc, że wyrównanie płatności następuje. Przyjmując wielkości płatności z tabeli 3, dla Polski wzrosły one o 7\% w porównaniu z rokiem 2013. Są one jednak niższe od średniej wynoszącej 276 euro/ha, a także od $90 \%$ średniej wynoszącej 250 euro/ha. 


\section{Bibliografia:}

Agenda2000. Pobrane z: http://europa.eu/legislation_summaries/enlargement/2004_and_ 2007 enlargement/160001_en.htm, data dostępu 20150915.

Annex F of the Health Check, I. Impact of a change towards flatter rates of direct payments, Dec. 2007 Pobrane z: http://ec.europa.eu/agriculture/rica/pdf/hc0301_impact_flatter.pdf/ data dostepu 20150830.

Commission staff working paper impact assessment, Common Agricultural Policy towards 2020, Annex 3. European Commission, Brussels 2011.

Cooper, T., Hart, K. and Baldock, D. (2009): The provision of public goods through agriculture in the European Union, Report for DGAGRI. Institute for European Environmental Policy. London.

http://capreform.eu/the-distribution-of-cap- payments-by-member-state/, data dostepu: 2015.09.10.

http://ec.europa.eu/agriculture/cap-post-2013/index_en.htm.

http://www.slideshare.net/nowastepnica/wpr-do-2020-propozycje-ustawodawcze-komisji/, data dostepu 2015.08.28.

Komunikat Komisji dla Rady, Parlamentu Europejskiego, Komitetu Społeczno-Ekonomicznego i Komitetu Regionów. The CAP Towards 2000: Meeting the Food, Natural Resources and Territorial Challenges of the Future. Komisja Europejska . (2010). Bruksela.

Kowalski, A., Rowiński, J., Wigier, M. (2001). Kwoty produkcyjne, powierzchnie bazowe i plony referencyjne - Analiza różnych wariantów negocjacyjnych. Warszawa: UKIE.

Krzyżanowski, J.T. (2015). Wspólna polityka rolna Unii Europejskiej w Polsce. Warszawa: CeDeWu.

Krzyżanowski, J.T. (2009). Wspólna polityka rolna Unii Europejskiej - wybrane zagadnienia. Warszawa: SGGW.

Krzyżanowski, J.T. (1993). Ceny rolne jako narzędzie regulowania produkcji rolniczej. Warszawa: SGGW.

Stankiewicz, D. (2001). Płatności bezpośrednie w Unii Europejskiej. Warszawa: Kancelaria Sejmu Biuro Studiów i Ekspertyz.

Sprawozdanie z posiedzenia Rady UE ds. Rolnictwa i Rybołówstwa w dn. 18-20 listopada 2008 r. Materiały wewnętrzne MRiRW. (2008). Warszawa: MRiRW. 
JULIAN KRZYŻANOWSKI

Institute of Agricultural and Food Economics

- National Research

Warsaw

\title{
TOWARDS EQUAL LEVEL OF DIRECT PAYMENTS IN POLAND AND OTHER EUROPEAN UNION COUNTRIES
}

\begin{abstract}
Summary
The paper tackles the problem of making direct payments in the EU countries more equal. Two sets of indices and their evolution are being presented: payment rates per product and per hectare of eligible area. The need of redistribution of direct payments is being stressed, followed by the discussion on different scenarios of distribution among member states. The model finally accepted by the EU institutions and member states is presented, as well as calculations of shifts in per hectare rates due to direct payments redistribution. The results show increase od direct payments rate in Poland, but it is still slightly below EU average.
\end{abstract}

Key words: direct payments, European Union, the MacSharry reform, rates of direct payments, reference yield, redistribution of payment

Zaakceptowano do druku - Accepted for print: 03.12.2015. 